\title{
Developing Our Voices: Pacific Early Career Academics' Journeys in Aotearoa New Zealand
}

Tim Baice, Sereana Naepi, Seuta 'afili Patrick Thomsen, Karamia Muller, Marcia Leenen-Young, Sam Manuela, Sisikula Sisifa

\begin{abstract}
The proportion of Pacific academics in permanent confirmation path positions at New Zealand universities (1.4 percent) continues to lag far behind the Pacific share of New Zealand's population (7 percent). In this paper, we use a thematic talanoa to explore the experiences of Pacific early career academics (PECA) at the University of Auckland to highlight the key themes, challenges and features of our daily lives in the colonial, Western, and Pākehā institution that is the university. This paper sheds light on the systemic and structural barriers that impact PECA journeys through higher education and suggests actions that universities in New Zealand can take to further support, nurture, and develop PECA pathways into and upward through the academy.
\end{abstract}

\section{Introduction}

The success of early career academics is a growing area of research in higher education. Recent research has shown that Pacific peoples continue to be under-underrepresented in faculty positions across Aotearoa, signalling a need for universities to not only focus on, but recruit, retain, and promote Pacific early career academics (PECA). ${ }^{1}$ This paper aims to shed some light on how PECA experience universities, in an effort to increase understanding of our lived realities within New Zealand universities, offering practical solutions for the successful retention and promotion of PECA. This paper will contextualise the significant under-underrepresentation of PECA by considering previous research on emerging academics in New Zealand and the experiences of racialised bodies working in universities. This paper then explores three questions: (1) what is challenging about being a Pacific early career academic; (2) what strengths do we see in the Pacific academic community; and (3) how are we currently supported, and how could we be better supported? Finally, we offer ways forward for the retention and promotion of PECA in New Zealand.

\section{Context}

Early career academics in New Zealand are likely to be women, Caucasian, under 40, and more than half (56 percent of new hires within New Zealand universities) are born overseas, of whom only 1 percent are Pacific. ${ }^{2}$ This demographic information provides insight into continued patterns of under-underrepresentation for Pacific peoples in academia; we are simply not being hired by New Zealand universities. A common response to this is that there are not enough Pacific doctorates; however, Naepi et al. identified areas within the New Zealand university system where significant opportunities to recruit and retain PECA are being lost, arguing for a system-wide approach that puts the onus on universities to consider what changes they could make to support Pacific success within universities. ${ }^{3}$

Pacific peoples constitute 7 percent of New Zealand's total population, and yet census data from 2018 highlights that Pacific doctoral qualified academics make up a mere 1.4 percent of university

Journal of New Studies NS33 (2021), 10-24 https://doi.org/10.26686/jnzs.iNS33.7379 
lecturers in Aotearoa New Zealand. ${ }^{4}$ Pacific peoples traditionally have a strong and recent migrant history from various islands in the Pacific; now, however, more than 60 percent of New Zealand's Pacific population have been born in New Zealand. ${ }^{5}$ Naepi's "Why Isn't My Professor Pasifika? A Snapshot of the Academic Workforce in New Zealand Universities" shows the number of Pacific academics in Aotearoa has barely improved between 2012 and - 2017, whilst data from the University of Auckland shows a sharp reduction in the number of Pacific academic staff between 2015- and 2017. ${ }^{6}$ The data on Pacific academics in higher education mirrors global patterns of the exclusion of Indigenous communities from universities. In Australia, Indigenous Aboriginal and Torres Strait Islanders made up less than 3 percent of the academic staff workforce $^{7}$; in the United States and Canada, Native Americans and Aboriginal Canadians made up less than 0.5 percent and 1 percent of faculty respectively. ${ }^{8}$ The situation is similar for Māori academics who make up less than 5 percent of the academic workforce in Aotearoa New Zealand. ${ }^{9}$ These figures have largely remained stagnant between 2012- and 2017, which raises important questions about the commitments of universities to building a sustainable Māori academic workforce and honouring commitments to Te Tiriti o Waitangi. ${ }^{10}$

The awareness of the experiences of Pacific academic staff in navigating the terrain of the higher education landscape in Aotearoa New Zealand is growing. ${ }^{11}$ Recent analysis of early career academic experiences in New Zealand suggest they face several challenges. Sutherland highlights that the satisfaction and research productivity of early career researchers is higher for New Zealand than for elsewhere, but that there is a struggle to find a sense of work-life balance, compounded by unrealistic expectations and the disparity between different disciplines and universities' support of early career academics. ${ }^{12}$ Sutherland argues that there are a number of ways early career academics can be supported: (1) departmental support is vital; (2) the importance of academic citizenship to the retention of faculty needs to be communicated; (3) relational agency (the ability to offer support and ask for support) should be encouraged; (4) Heads of Departments should consider early career academics' previous experiences when designing orientation and socialisation into the department. ${ }^{13}$ Sutherland also encourages individual responsibility, noting that early career academics need to be resourceful in how they seek help, demonstrate resilience, be aware of institutional norms, and be conscious of work-life balance. ${ }^{14}$ Despite these important findings, Pacific peoples were not explicitly included in their work. As such, this paper offers insight into how the authors, as PECA, experience this same space, taking into consideration that the experiences of early career academics in New Zealand changes when you are a "space invader." 15

Inclusion of a Pacific lens is critical for understanding the complexities of early career academic experiences, as our perpetual under-underrepresentation suggests flaws in the recruitment, retention, and promotion of Pacific academics. Recent research into how Pacific peoples experience the academy strongly point to New Zealand universities remaining spaces of exclusion. ${ }^{16}$ This exclusion can in part be attributed to the foundational whiteness of universities. ${ }^{17}$ They are spaces and places where a monocultural knowledge system based on Western values is reproduced by those who have a significant investment in continuing their dominance in knowledge production. ${ }^{18}$ Higher education spaces in settler-colonial contexts such as Australia, Canada, New Zealand, and the USA have traditionally been dominated by Western ways of "knowing and being"," thereby privileging dominant neoliberal discourses of education. This has 
led to an "epistemological dominance" of institutionalised Eurocentric education norms. ${ }^{19}$ This highly political context privileges this kind of knowledge at the expense of other epistemologies and pedagogies. In addition to alienating other forms of knowledge, opportunities for collaboration or dialogue across different epistemological sets are limited, given the presupposed universal, neutral, and supreme nature of Eurocentric knowledge. ${ }^{20}$

The limited number of PECA can also be attributed to the neoliberal value system that New Zealand universities subscribe to, reducing everything to an input/output measurement. ${ }^{21}$ This can have a significant impact on peoples whose value system lies in relationship building. ${ }^{22}$ Organisational theories in higher education are largely grounded in structural functionalism, with little to no attention paid to other epistemologies and ways of being. ${ }^{23}$ Structural functionalism is criticised for its inability to consider issues of power, privilege, identity, oppression, equity, and social justice; Capper has argued further that education practices that emanate from structural functionalism "perpetuate inequities and social injustice." 24

This epistemological hierarchy can be observed throughout the university structure, through dominant ideas about coursework and pedagogy infiltrating how key concepts such as "scholarship,", "quality,", and "success" are defined. ${ }^{25}$ Regarding pedagogy, traditional theories of learning have failed to recognise the wider dispositions, cultural knowledge, and influences of family and community for diverse learners. ${ }^{26}$ Epistemological dominance is exerted through the use of broad concepts such as diversity and inclusion that have enabled the reproduction of epistemological dominance and the silencing and othering of those denoted as "diverse." 27 Diversity, defined in this way, typically refers to those who are "different," often minorities within a majority group context; "diversity" offers "conditional hospitality," rendering difference and otherness at the edges. The inclusion of Indigenous knowledges as an "add- on" or an afterthought to complement course curricula is a prime example of othering: the relegation of other (often Indigenous) knowledges to the edges of mainstream curricula and consciousness. ${ }^{28}$

\section{Methodology/Method}

The writers of this paper recognise that we are not the first to discuss the challenges and strengths of being PECA. This conversation happens often in the undercommons of universities by not only Pacific but other racialised groups. As such we wish to recognise that what we have to offer is a small contribution to an ongoing series of talanoa (dialogue) - both a cultural practice and a recognised Pacific methodology - amongst Pacific scholars, that continues as a way to strengthen our relationships to each other and our communities. ${ }^{29}$ In particular, this paper arose from a collective of emerging Pacific academics who recognise the neo-neoliberal values of the university mean that if we are to meet as an official group (input of time) then there would need to be an output (this publication). ${ }^{30}$ It is in this way we slowly chip away at the university value system, by taking the expectation of individual gain and instead producing collaborative work that strengthens our relationships to each other and our community, and enriches the higher education research field.

Our research method is framed with all of this in mind. We agreed to a basic premise regarding this article: that it is an opportunity to articulate what is challenging and what is inspiring about being a Pacific early career academic, and then for each to contribute a vignette. Vignettes in social 
science qualitative research are used to elicit responses to a proposed set of questions/scenarios and facilitate a deeper exploration of individual responses. ${ }^{31}$ Early vignettes indicated that we could answer three questions: (1) what is challenging about being a Pacific early career academic; (2) what strengths do we see in the Pacific academic community; and (3) how are we currently supported and how could we be better supported? Once we had each contributed our vignettes, our lead author captured seven key themes that spoke to the individual experiences.

We define PECA as someone of Pacific heritage employed in a full-time permanent position at the university who has transitioned into this role within the past five years. This limited definition acknowledges that PECA in precarious employment do not have the benefit of protection around freedom of speech that permanent academics do. We are mindful of how this may impact career progression for those without permanent contracts. ${ }^{32}$

\section{Findings}

The data produced from the shared experiences of seven PECA were grouped thematically, initially producing seven key themes. A reflexive thematic analysis was used to analyse and code the data and to generate initial themes, which were then reviewed and refined to combine thematically similar sub-subthemes. ${ }^{33} \mathrm{We}$ draw on the creative methodological practices of Pacific researchers across higher education who refashion conventional methods to incorporate Pacific research methods and values. ${ }^{34}$ For example, Thomsen's research uses the general principles of a thematic analysis but makes direct links to principles that are rooted in Pacific ways of being and knowing. ${ }^{35}$ A thematic talanoa analysis includes telling a story where the theory is combined with the narrative in conversation, which differs from a conventional thematic analysis that can still be extractive. ${ }^{36}$ Many of the themes are interconnected. In response to the first research question, the first four themes highlight the various challenges PECA face daily in navigating the university landscape. The remaining three themes respond to the second and third research questions by highlighting the strengths-based coping mechanisms that support the academic development and the strengthening of academic identities within the academy.

The vignettes are presented as summaries of the combined talanoa, as opposed to the opinions of specific individuals. While we recognise the diversity of PECA membership, and the significance of that diversity, the authors committed to the act of sharing our combined experiences in this collective manner to set a foundation to represent our collective voices. This allows for further publications that contain more nuanced experiences and understandings based on our respective institutional positionalities within higher education. As a recently developed network within the university, this publication is a sounding board, representing our commitment to working collectively to support one another in our collective navigation of higher education.

The seven key themes identified are:

1. Lack of academic capital

2. Isolation and loneliness

3. Systemic and structural tensions

4. Cultural labour/taxation

5. Institutional support 
6. Strength of Pacific values and connections

7. Support from Pacific colleagues

\section{Lack of Academic Capital}

A consensus amongst the narratives from PECA was a lack of academic capital - that is, a lack of an early exposure to academia - which has contributed to the current low number of Pacific academics. Often, PECA were the first in their family to attend university, and spoke of the lack of accessible Pacific role models within families and their broader communities. The responses mirror the lack of academic capital that broadly characterises the journey of Pacific generally within the academy: ${ }^{37}$

Growing up in a poor South Auckland household meant that my exposure to the world of academia was only ever through my experiences as a learner once I entered university. Bereft of any role models or familial social capital in the field has meant that navigating the "academy" has been tremendously difficult.

I do not have any familial or community reference points to draw from. Many of my nonPacific colleagues who I have met and those I studied with as a PhD student in the United States had parents who were college professors or came from middle class backgrounds and had been conditioned early on in their lives to understand what is needed to be able to survive and thrive in academia. I see this as one of the biggest barriers to Pacific scholars entering academia.

\section{Isolation and Loneliness}

PECA spoke of the burden of often being the only (or one of the very few) Pacific members of academic staff in their respective departments. The isolation had significant implications on their ability to thrive holistically as Pacific peoples and as academic staff, mirroring the experiences of other Pacific staff: ${ }^{38}$

The profound loneliness negotiating academia is the same reason I understand it is important to remain in it. That to stay and develop your voice is to take up and create space, for others like us. Right now, I am the only Pasifika woman in my faculty with a full-time contract. It is a daily occurrence when I find myself the only Pasifika person in the meeting, in the staffroom, at a staff event, or presenting to students. Usually, I am the only Pasifika woman, even when there is a bigger staff pool if the meeting includes professional staff. I sometimes look at my Pālāgi $i^{39}$ colleagues and am incredulous that they will likely never-never - in their whole career ever have to feel the isolation that comes with being one of the under-represented.

My time in academia so far has largely been positive but peppered with moments of frustration. These frustrations are all connected to an underlying issue of there being so few of us in the academy. Isolation in academia is common.

Not only do we need to be present, but we also need to be assertive and comfortable to push for our students - which is a challenge as an emerging academic when you are often the only Pasifika voice in the room. There is no training in this. 


\section{Systemic and Structural Tensions}

Linked to the previous theme of isolation and loneliness, the university often proved an inhospitable place for Pacific itulagi (worldviews), diverse ways of being, teaching and learning. ${ }^{40}$ PECA spoke of the disconnect of non-Pacific colleagues from the lived realities of Pacific students, and how this often resulted in grand misperceptions and poor judgement from such staff. Like the respondents in Kidman and Chu's study, PECA found themselves constantly having to respond to and correct colleagues, often advocating for the broader interests of both Pacific students and staff: $^{41}$

Like many of my Pacific colleagues, I have the unenviable challenge of privileging multiple Pacific itulagi within an institution whose monoculturalism is both domineering and unforgiving in its dominance and sidelining of Indigenous ways of teaching, learning and being.

Pālāgi colleagues have little self-awareness of how Indigenous, Pasifika, Māori discourse has developed, and the nuance of deficit framing, or how they are no longer (they never were) the experts to advise us on pathways to self-determinacy on our terms. I find myself often listening to un-invited, wide-ranging Pālāgi perspectives that reveal ontological dissonance with Pasifika worldviews, the penultimate of outdated framing: speaking authoritatively about Pasifika, their peoples, and communities as a deficit subject because you have Pasifika friends or worked with a Pasifika community that one time.

I remember the deficit framing of Pasifika in lecture content when I was a student. It was always difficult to deal with, but it's a different ball game as academic staff. I can now see and challenge the deficit framing within the system, but it gets very frustrating and tiring. There's a back and forth among my colleagues asking, "How can we improve the pass rates of our Māori and Pacific students?" versus "What is it about how we are teaching, and the school is structured that is not benefitting our Māori and Pacific students in the same way?" A kind of "achievement gap" vs "opportunity gap" positioning.

The school overall seems to really want Pacific to thrive but there are blindspots like power and structure that need to be addressed to succeed. They have talked to me about burnout and making sure I don't, but they are failing to recognise it is the wider university structure that causes that burnout and until that is addressed Pacific academics will continue to be overloaded as we try to meet the expectations of two worlds.

Although aware of the need to respond to and often correct the misperceptions of non-Pacific colleagues, PECA are all too aware of the implications their advocacy could have on their employment as staff and any future hopes of progression:

Sometimes it's also hard because I'll point out racism to a colleague and they will say hey let's report it without really understanding what it means to be Pacific and a womanreporting that racism endangers my progression, yes, the person who did it may get reprimanded, but they will remember what I did and have the power to slow my progression or viability in tenuous times. 
The-academic-at-work-what-I-feel-I-can-say-voice-says: I think research demonstrates that Pacific pass rates are more complex than simply lack of attendance. There are countless instances like this. This holding back of what I would like to say in-my-headvoice while redirecting Pālaggi colleagues to the greater systemic issues with the what-Ifeel-I-can-say has significantly characterised developing my voice.

I found spaces that allowed me to flourish as an emerging Pasifika academic and others where my drive and advocacy for Pasifika peoples was actively discouraged by those in leadership positions.

At best these moments provide for the sassiest laugh sessions with fellow Pasifika early career academics, at worst they can trigger depressive episodes that I manage as best as I can without inviting attention from my line manager or colleagues with antidepressants, publicly funded mental health services, personally funded clinical psychology, and periods of low scholarly productivity. These periods I count myself lucky to have such employment, although it does concern me that others like me might be facing greater precarity.

\section{Cultural Labour/Taxation}

Institutional cultural dissonance has led to PECA feeling pressure to perform additional responsibilities in both advocating for and supporting Pacific learners. ${ }^{42}$ PECA were often called upon by non-Pacific colleagues as remedies to the issues presented to them by their Pacific learners. This theme builds on the key tension identified earlier: the disconnect between, on the one hand, the priorities and expectations of the university for students, and on the other, the diverse experiences and ways of learning of Pacific learners. Although PECA are generally committed to the service and advocacy of Pacific students, this was often done in addition to already heavy workloads:

I get a lot of emails from colleagues asking for advice about engaging with Pacific students, communities etc. It's a kind of labour that doesn't get a lot of recognition. Sometimes the labour feels like a lot of supporting staff who really want to "make sure I'm being culturally appropriate" - a bit of hand holding and reassuring.

One of the central challenges with being an early career Pasifika academic is that there are so few of us, that we very fast become stretched thin as we are pulled in different directions and asked to represent Pasifika people in multiple forums. There are simply not enough of us and much of what we do is "invisible" to the university's expected job description. One central aspect of this is the social and emotional support we give our students outside of the bounds of what is expected, and the steps we take to advocate for them.

Within the University the mindset and structures are designed to support the concept of the Western student who has no responsibility beyond passing their classes, with enough money to live comfortably while they do this; a picture so far removed from our Pasifika students that it is laughable. We need to represent our Pasifika students in these Western

Journal of New Studies NS33 (2021), 10-24 https://doi.org/10.26686/jnzs.iNS33.7379 
forums so we can give voice to the lived realities they face, and we need to do that loud and in full colour for people to recognise the importance of what we are saying.

We could make the political statement of not following this advice, but we know we won't get promoted and we need more Pacific people higher up the academic ladder. Sometimes I see what our more senior Pacific colleagues have achieved, and I am disheartened that they are not professors yet; the message is clear-serving your community will not get you promoted even though that's what universities claim to be about.

\section{Institutional Support}

Despite the challenges identified in the first four themes, PECA were able to share examples of institutional practices that contributed positively to supporting their academic development. Here, colleagues identified helpful departmental practices such as structured mentoring and guidance provided by departmental heads who were often non-Pacific. These processes provided clearer guidance around navigating departmental/faculty systems and progression pathways:

My faculty have implemented mentoring programmes for emerging researchers of which I was invited to be part of. I was thankful for time in them and for the wisdom I gained from my peers and seniors/mentors. The skills, support, and guidance were mainly centred on career advancement and promotion. This was useful in its own right and I don't want to detract from the benefits I gained from it.

I come from a really supportive department, they have arranged mentoring, are minimising my service and check in on me regularly.

To better support the development and progression of PECA, there are particular priorities of the academy that must be amended to accommodate Pacific priorities of service to communities:

A group publication that supports all of us is of less value than an individual publication. But it is in group publishing those relationships are built. Open access publication means my community can access my work, but that is devalued. I've been advised to publish internationally not domestically, and by international they mean European and North American journals. It angers me that we aren't supporting local journals that our community can access easily in measuring the "success" of an academic.

Promotion needs to consider that different academic communities have different measures of a successful academic. Senate who signs off on promotion needs to understand this - it is unfair to have a department, then school say yes because they understand the limits of the structure to then have the wider university say no because they haven't critically engaged in their own value system.

\section{Strength of Pacific Values and Connections}

PECA discuss how their Pacific cultural values and traditions have acted as protective strengths that validate their cultural identities within the academy. This allows for the incorporation of Pacific cultural knowledge, pedagogies, and methodologies to support their work and the work of their fellow PECA: 
I think a lot about being raised in a Samoan household and how that's affected me. In particular, I was brought up to understand Samoan values around tautua or service as a way to frame and understand your work.

As social scientists, we know relationships are important for wellbeing. As Pasifika, we know relationships are the foundation of our being. The disconnect between the ways we conceptualise relationships as Pasifika within a largely Eurocentric institution can make life difficult sometimes. Relationships in academia can become so transactional that my connection and identity as an academic becomes less meaningful.

Our greatest strengths are our relationships. Although we are a small collective, and we are spread across the university, the bonds between us all are some of the strongest collegial relationships I have ever come across. There are times I don't need to speak in depth because our shared experiences mean we already know. A simple question of "How's everything going?" can be explained with a roll of the eyes and received with a knowing smile and shared laugh at our own expense. It is interactions like this where I know I am with people I need to be with. Where we can simultaneously be each other's shoulder to lean on and hype-person. Before entering academia, I had heard of the fierce competition of academia, the "publish or perish mentality" and I geared myself to get used to it. I thought I must know and work the system to survive its individualised competitiveness. However, it is the compassion and support of our unofficial Pacific networks that keeps me safe.

Our relationships as Pacific staff are informal and formal at the same time. We offer each other career advice and make jokes at each other's expense. It is a kind of collegiality that feels the same as if you were visiting a cousin at their home. We are each other's constructive critics and hype people. I like not having to start at square one and providing broader context to Pacific experiences with our emerging Pacific academics, we can get straight to business.

\section{Support from Pacific Colleagues}

All PECA were unanimous in the fundamental mentoring role senior Pacific academics provide:

Since I transitioned into a permanent role, my direct manager who is a senior Pacific academic has been guiding my progression plan and pushed me out of the department to find a Pacific academic mentor. The first person I asked gave me a resounding yes. The community of Pacific scholars and their strength as a network, their capability to selfdetermine for themselves the support their younger colleagues like me need, is what will ultimately lift our presence in academia and move us forward.

I am incredibly thankful for the connections I have with other Pacific staff-those that have been here longer than me and helped pave the way, and those that I have started this journey alongside. We have shared experiences that don't need to be elaborated on because they are known-it's like a taken for granted kind of thing within Pacific spaces that you have to explain and justify in other spaces. Because our relationships are 
fundamental to our ways of being, we very easily form networks of support. It is the quality and focus on these relationships which is perhaps the greatest strength that we have (despite our small numbers), and something that the university could never provide.

Currently I receive mentoring from a senior Pacific colleague, it's nice to have somebody who goes to the same meetings as me, recognises the same problematic behaviour and then we can talk about it.

Our senior Pacific mentors have also been invaluable, they help guide us on this path and many of them have laid the pathway for us. It amazes me how invested and supportive they are in our success.

\section{Discussion}

The narratives above offer a new way to understand early career academic experiences by exploring the lived experiences of PECA. While several barriers are identified (lack of academic capital, isolation and loneliness, systemic and structural tensions, cultural labour/taxation) we also identified the strengths we bring as a community (strength of Pacific values and connections, support from Pacific colleagues, and ways in which institutions can support us).

Although the themes produced in this article are relevant to Pacific academics, critical connections can be made to previous research conducted by Māori academics. Mercier et al. showed that connections between and with Māori academics provided especially empowering and positive support. ${ }^{43}$ Māori academic early career researcher networks were also identified as a means of strengthening the support necessary for individuals to navigate the institution as Māori. Moreover, such networks provided critical spaces where whanaungatanga (relational networks) are grown within the university that serve as spaces of refuge and retreat from the battleground of policy and decision-making. ${ }^{44}$

PECA face similar socialisation issues to those faced by other early career academics, but it is also clear that as "space invaders" there is an extra layer of complexity in this experience. ${ }^{45}$ Our findings suggest that the challenges Sutherland noted for early career academics in New Zealand are compounded for PECA, as we must also engage with systemic and structural tensions and cultural labour and taxation whilst attempting to locate a work-life balance, engage as good academic citizens, and practice relational agency. ${ }^{46}$

The systemic and structural tensions experienced by PECA mean that engaging as good academic citizens can be highly problematic for us. It is difficult to contribute positively to a structure in which you experience the isolation and loneliness outlined above and the exclusion recorded in previous research. ${ }^{47}$ Instead, as outlined by the experiences above we become overloaded with service requests while attempting to navigate a space that is fundamentally unfamiliar to us all, while also being aware that the university itself holds onto policies and processes that continue to under-undervalue our work. The expectation that we could be good academic citizens whilst attempting to reconcile our exclusion leads to the burn- out discussed above.

Earlier literature identified the need to develop "relational agency" to be successful as early career researchers; that is, being able to ask for and provide help to others. The stories above suggest that

Journal of New Studies NS33 (2021), 10-24 https://doi.org/10.26686/jnzs.iNS33.7379 
early career academics practice relational agency amongst our own Pacific academic community, both seeking support from senior Pacific academics and supporting other Pacific early career researchers. ${ }^{48}$

\section{Strength of the Pacific Academic Community and Institutional Support}

What remains clear from the narratives shared is that PECA continue to find strength and support within the Pacific academic community. This needs to be expanded to include the entire academic community, which may take some significant structural change on behalf of the university. The stories shared about institutional support begin to give us some idea of what this may look like: supportive management, meaningful mentoring relationships, and recognition of Pacific epistemologies and ontologies as key to institutional success.

Pacific peoples have long been heralds of relational ontological practices, and the narratives above indicate that these practices are influencing our success as PECA. Fundamental aspects of the relational agency referred to earlier are critically embedded in Pacific cultures. This is captured in Pacific notions of the vā, often referred to as "sociospatial connections," the "space between people and things." 49 The vā not only refers to relationships with people, it also speaks to ecological relationality: relationships with the land, sea, and heavens. ${ }^{50}$ Notions of vā (Tonga, Sāmoa, Rotuma, Tahiti) and wā (Hawai'i, Aotearoa) are underpinned by core common Pacific values that include 'ofa, alofa, aroha, aloha, arofa, aro'a (love and generosity), langimalie, langmalie, rangimarie (equilibrium, harmony, holistic wellbeing), faka'apa'apa, fa'aaloalo (respect), and fetokoni'aki, feososoani (mutual assistance). ${ }^{51}$

Pacific understandings of vā represent an embracing of the holistic being. This article has shown that Pacific practices of relationality are viewed as a strengths-based approach to supporting the academic development of emerging Pacific academics. The mutual reciprocity of nurturing and sustaining the vā continues to be a pivotal tool for emerging Pacific academics in navigating the university landscape. Despite the monocultural focus on the individual within the academy, Pacific academics continue to find ways to acknowledge, validate and reaffirm Pacific sociocultural practices within academic contexts. This adoption of cultural practices within an institutional context contributes to building a sense of cultural interconnectedness between PECA. ${ }^{52}$ Pacific approaches to relationality have also been prominently featured in extensive research on pedagogy that enhances learning outcomes for Pacific students. Emerging Pacific academics, therefore, have a lot to offer the university, and universities should invest in the spaces and resources necessary to enable and further strengthen the development of relational agency.

\section{Conclusion}

Despite the significant challenges PECA face in New Zealand universities, we continue to engage in relational practices that bring strength to our academic practices. Universities need to begin to consider how they will match our strengths with support in ways that enable us to successfully contribute to our communities while participating fully in the university. In this way both Pacific communities and the university community can move forward together and imagine a future where we both grow in strength and solidarity. This article highlights Pacific practices and understandings of relational agency that are key to supporting the development and progression of early career Pacific academics. It joins a wealth of research that highlights key institutional

Journal of New Studies NS33 (2021), 10-24 https://doi.org/10.26686/jnzs.iNS33.7379 
practices that are conducive to the development of Indigenous early career academic staff, providing specific detail on how to support Pacific staff in the context of higher education in Aotearoa. ${ }^{53}$

\footnotetext{
${ }^{1}$ Sereana Naepi, "Why Isn't My Professor Pasifika? A Snapshot of the Academic Workforce in New Zealand Universities," MAI Journal: A New Zealand Journal of Indigenous Scholarship 8, no. 2 (31 July 2019): 219-34, https://doi.org/10.20507/MAIJournal.2019.8.2.9; Sereana Naepi et al., "The Pakaru 'Pipeline': Māori and Pasifika Pathways within the Academy," The New Zealand Annual Review of Education 24 (2020): 142-59, https://doi.org/10.26686/nzaroe.v24i0.6338; Kathryn A. Sutherland, Early Career Academics in New Zealand: Challenges and Prospects in Comparative Perspective (Cham: Springer International Publishing, 2018), https://doi.org/10.1007/978-3-319-61830-2.

${ }^{2}$ Naepi, "Why Isn't My Professor Pasifika?" 219-34; Sutherland, Early Career Academics in New Zealand; see also Tara G. McAllister et al., "Why Isn't My Professor Māori? A Snapshot of the Academic Workforce in New Zealand Universities in New Zealand Universities." MAI Journal: A New Zealand Journal of Indigenous Scholarship 8, no. 2 (31 July 2019): 235-49, https://doi.org/10.20507/MAIJournal.2019.8.2.10.

${ }^{3}$ Naepi et al., "The Pakaru 'Pipeline,"” 142-59. See also Joanna Kidman and Cherie Chu, "'We're Not the Hottest Ethnicity': Pacific Scholars and the Cultural Politics of New Zealand Universities," Globalisation, Societies and Education 17, no. 4 (8 August 2019): 489-99, https://doi.org/10.1080/14767724.2018.1561247; Sereana Naepi et al., "A Cartography of Higher Education: Attempts at Inclusion and Insights from Pasifika Scholarship in Aotearoa New Zealand," in Global Teaching: Southern Perspectives on Teachers Working with Diversity, ed. Carol Reid and Jae Major (Palgrave Macmillan, 2017), 81-99.

${ }^{4}$ Statistics New Zealand, "Pacific Peoples, Not Further Defined Ethnic Group," from 2018 census data, https://www.stats.govt.nz/tools/2018-census-ethnic-group-summaries/pacific-peoples-not-further-defined. ${ }^{5}$ Ministry for Pacific Peoples, "Pacific Aotearoa Lalanga Fou" (Ministry for Pacific Peoples, 2018), https://www.mpp.govt.nz/assets/Reports/Pacific-Aotearoa-Lalanga-Fou-Report.pdf.

${ }^{6}$ Naepi, "Why Isn't My Professor Pasifika?" 219-34.

${ }^{7}$ Christine Asmar and Susan Page, "Pigeonholed, Peripheral or Pioneering? Findings from a National Study of Indigenous Australian Academics in the Disciplines," Studies in Higher Education 43, no. 9 (2 September 2018): 1679-91, https://doi.org/10.1080/03075079.2017.1281240.

${ }^{8}$ Stacey Kim Coates, Michelle Trudgett, and Susan Page, "Indigenous Higher Education Sector: The Evolution of Recognised Indigenous Leaders within Australian Universities," The Australian Journal of Indigenous Education (2020): 1-7, https://doi.org/10.1017/jie.2019.30.

${ }^{9}$ McAllister et al., "Why Isn't My Professor Māori?" 235-49.

${ }^{10}$ McAllister et al., "Why Isn’t My Professor Māori?" 235-49.

${ }^{11}$ Tim Baice et al., "Responding to the Call: Talanoa, Va-vā, Early Career Network and Enabling Academic Pathways at a University in New Zealand," Higher Education Research and Development 40, no. 1 (2 January 2021): 75-89, https://doi.org/10.1080/07294360.2020.1852187; Kidman and Chu, "We're Not the Hottest Ethnicity," 489-99; Patrick Thomsen et al., "In Our Own Words: Pacific Early Career Academics (PECA) and Pacific Knowledges in Higher Education Pedagogical Praxis," Higher Education Research and Development 40, no. 1 (2 January 2021): 49-62, https://doi.org/10.1080/07294360.2020.1852188; Patrick Saulmatino Thomsen et al., "Practising Pacific Pedagogies during New Zealand's Level Four Lockdown: Pacific Early Career Academics and COVID19," Waikato Journal of Education 26 (5 July 2021): 149-61, https://doi.org/10.15663/wje.v26i1.754; Sereana Patterson, "Beyond the Dusky Maiden : Pasifika Women's Experiences Working in Higher
} 
Education" (doctoral thesis, The University of British Columbia, 2018), https://dx.doi.org/10.14288/1.0370998; Damon Salesa, Lalava: Pacific People and the University of Auckland (University of Auckland, 2018); Tanya Wendt Samu, "Spirit, Space and Stewardship: A Collective Approach to Becoming Pacific Women in the Academe," in Talanoa: Building a Pasifika Research Culture, ed. Peggy Fairburn-Dunlop and Eve Coxon (Dunmore Publishing, 2014), 189-207.

${ }^{12}$ Sutherland, Early Career Academics in New Zealand.

${ }^{13}$ Sutherland, Early Career Academics in New Zealand.

${ }^{14}$ Sutherland, Early Career Academics in New Zealand.

${ }^{15}$ Nirmal Puwar, Space Invaders: Race, Gender and Bodies Out of Place, first edition (Oxford and New York: Berg Publishers, 2004).

${ }^{16}$ Baice et al., "Responding to the Call," 75-89; Cherie Chu, Ivy Abella, and Sean Paurini, Educational Practices That Pacific Learners in Tertiary Education (Ako Aotearoa, 2013), https://ako.ac.nz/assets/Knowledge-centre/NPF-10-001A-Pasifika-Learners-and-Success-in-TertiaryEducation/RESEARCH-REPORT-Educational-Practices-that-Benefit-Pacific-Learners-in-TertiaryEducation.pdf; Kidman and Chu, "We're Not the Hottest Ethnicity," 489-99; Sereana Naepi, "II Didn't Come to Play': Pasifika Women in the Academy," in Critical Reflections and Politics on Advancing Women in the Academy, ed. Taima Moeke-Pickering, Sheila Cote-Meek and Ann Pegoraro (IGI Global, 2020), 52-69, DOI: 10.4018/978-1-7998-3618-6; Naepi et al., "A Cartography of Higher Education," 8199; Naepi et al., "The Pakaru 'Pipeline,"” 142-59; Thomsen et al., "In Our Own Words," 49-62.

${ }^{17}$ C. Ahenakew and Sereana Naepi, "The Difficult Task of Turning Walls into Tables," in Sociocultural Realities: Exploring New Horizons, ed. Angus Mcfarlane, Sonja Macfarlane and Melinda Webber (Canterbury University Press, 2015), 181-94; Sara Ahmed, On Being Included: Racism and Diversity in Institutional Life (Durham and London: Duke University Press, 2012); Ramón Grosfoguel, "The Dilemmas of Ethnic Studies in the United States: Between Liberal Multiculturalism, Identity Politics, Disciplinary Colonization, and Decolonial Epistemologies," Human Architecture: Journal of the Sociology of Self-Knowledge 10, no. 1 (1 January 2012), https://scholarworks.umb.edu/humanarchitecture/vol10/iss1/9; Ramón Grosfoguel, "The Structure of Knowledge in Westernized Universities: Epistemic Racism/Sexism and the Four Genocides/Epistemicides of the Long 16th Century," Human Architecture: Journal of the Sociology of Self-Knowledge 11, no. 1 (22 September 2013), https://scholarworks.umb.edu/humanarchitecture/vol11/iss1/8; Andrew Pilkington, "The Interacting Dynamics of Institutional Racism in Higher Education," Race Ethnicity and Education 16, no. 2 (1 March 2013): 225-45, https://doi.org/10.1080/13613324.2011.646255; Puwar, Space Invaders.

${ }^{18}$ Nana Osei-Kofi, Riyad A. Shahjahan, and Lori D. Patton, "Centering Social Justice in the Study of Higher Education: The Challenges and Possibilities for Institutional Change," Equity and Excellence in Education 43, no. 3 (10 August 2010): 326-40, https://doi.org/10.1080/10665684.2010.483639.

${ }^{19}$ Naepi et al., "A Cartography of Higher Education," 81-99.

${ }^{20}$ Caroline Sarojini Hart, "Education, Capabilities and Sustainable Development," in New Frontiers of the Capability Approach (2018): 617-42, https://doi.org/10.1017/9781108559881.026; Naepi et al., "A Cartography of Higher Education," 81-99.

${ }^{21}$ Mark Olssen and Michael A. Peters, "Neoliberalism, Higher Education and the Knowledge Economy: From the Free Market to Knowledge Capitalism," Journal of Education Policy 20, no. 3 (1 January 2005): 313-45, https://doi.org/10.1080/02680930500108718.

${ }^{22}$ Meaola Amituanai-Toloa, "Tapuia (Space Made Sacred) in Bridging Research and Relationships: Brown Culture and Common sensical Ethics," AlterNative: An International Journal of Indigenous Peoples 3, no. 1 (1 June 2006): 200-219, https://doi.org/10.1177/117718010600300111; Tēvita O Ka'ili, "Tauhi Vā: Nurturing Tongan Sociospatial Ties in Maui and Beyond," The Contemporary Pacific 17, no. 1 (2005): 83-114, https://www.jstor.org/stable/23721933.

Journal of New Studies NS33 (2021), 10-24 https://doi.org/10.26686/jnzs.iNS33.7379 
${ }^{23}$ Colleen A. Capper, Organizational Theory for Equity and Diversity: Leading Integrated, Socially Just Education, first edition (Routledge, 2018), https://doi.org/10.4324/9781315818610.

${ }^{24}$ Capper, Organizational Theory for Equity and Diversity, 41.

${ }^{25}$ Naepi et al., "A Cartography of Higher Education," 81-99.

${ }^{26}$ Raewyn Si'ilata, "Va'a Tele: Pasifika Learners Riding the Success Wave on Linguistically and Culturally Responsive Pedagogies" (doctoral thesis, University of Auckland, 2014).

${ }^{27}$ Ahmed, On Being Included.

${ }^{28}$ Aiono Manu Fa'aea et al., "Navigating the Digital Va-vā: Centring Moana/Pacific Values in Online Tertiary Settings during COVID-19," Journal of Global Indigeneity 5, no. 1 (10 February 2021): 1-14, https://www.journalofglobalindigeneity.com/article/19436; Samantha Lafaiali 'i, "Ua Se Ana: The Promise of Equity" (master's thesis, University of Auckland, 2012).

https://researchspace.auckland.ac.nz/handle/2292/17630; Naepi et al., "A Cartography of Higher Education," 81-99; Nuhisifa Williams, "A View from the Back, Times between Spaces: Equality of Educational Opportunity and Pacific Students at a University" (doctoral thesis, University of Auckland, 2009).

${ }^{29}$ Vaioleti defines talanoa as a conversation, a talk, an exchange of ideas or thinking whether formal or informal. It allows people to engage in social conversation, which may lead to critical discussions or knowledge creation that allows rich contextual and inter-related information to surface as co-constructed. It requires researchers to partake deeply in the research experience rather than stand back and analyse. See Timote Masima Vaioleti, "Talanoa Research Methodology: A Developing Position on Pacific Research," Waikato Journal of Education 12 (2006): 21-34, https://researchcommons.waikato.ac.nz/handle/10289/6199; see also Melani Anae, "Research for Better Pacific Schooling in New Zealand: Teu Le Va-A Samoan Perspective," MAI Review 1, no. 1 (2010): 124, http://www.review.mai.ac.nz/mrindex/MR/article/download/298/298-2299-1-PB.pdf; Patrick S.

Thomsen, "Transnational Interest Convergence and Global Korea at the Edge of Race and Queer Experiences. A Talanoa with Gay Men in Seoul," Du Bois Review: Social Science Research on Race 17, no. 2 (2020): 411-28, https://doi.org/10.1017/S1742058X20000247.

${ }^{30}$ Olssen and Peters, "Neoliberalism, Higher Education and the Knowledge Economy," 313-45.

${ }^{31}$ Tom Wilks, "The Use of Vignettes in Qualitative Research into Social Work Values," Qualitative Social Work 3, no. 1 (2004): 78-87, https://doi.org/10.1177/1473325004041133.

${ }^{32}$ Naepi et al., "The Pakaru 'Pipeline," 142-59.

${ }^{33}$ Thomsen, "Transnational Interest Convergence," 411-28.

${ }^{34}$ Sereana Naepi, "Pacific Research Methodologies," in Oxford Research Encyclopedia of Education (Oxford University Press, 2020), https://doi.org/10.1093/acrefore/9780190264093.013.566.

35 Thomsen, "Transnational Interest Convergence," 411-28; Patrick S. Thomsen, "Coming-out in the Intersections: Examining Relationality in How Korean Gay Men in Seattle Navigate Church, Culture and Family through a Pacific Lens," Journal of Homosexuality 68, no. 6 (12 May 2021): 1015-36, https://doi.org/10.1080/00918369.2019.1695423.

36 Thomsen, "Transnational Interest Convergence," 411-28; Thomsen, "Coming-out in the Intersections," 1015-36; Naepi, "Pacific Research Methodologies."

${ }^{37}$ John Benseman et al., "Retaining Non-traditional Students: Lessons Learnt from Pasifika Students in New Zealand," Higher Education Research and Development 25, no. 2 (1 May 2006): 147-62, https://doi.org/10.1080/07294360600610388.

${ }^{38}$ Patterson, "Beyond the Dusky Maiden"; Tanya Wendt Samu, "Pacific Education: An Oceanic Perspective," MAI Review 1 (2010): 1-14, http://www.review.mai.ac.nz/mrindex/MR/article/view/311/379.html.

${ }^{39}$ Pālāgi is a Samoan term used to describe people of European/Western ethnicity. 
${ }^{40}$ In Samoan, itulagi can be directly translated as "side of heaven" (itu=side; lagi= heaven) and is used in Samoan research as a conceptual framework for a Samoan specific "lifeworld" or "worldview": Upolu Lumā Vaai and Aisake Casimira, Relational Hermeneutics: Decolonising the Mindset and the Pacific Itulagi (University of the South Pacific and Pacific Theological College, 2017).

${ }^{41}$ Kidman and Chu, "We're Not the Hottest Ethnicity," 489-99.

${ }^{42}$ Joanna Kidman and Cherie Chu, "Scholar Outsiders in the Neoliberal University: Transgressive Academic Labour in the Whitestream," New Zealand Journal of Educational Studies 52, no. 1 (1 July 2017): 7-19, https://doi.org/10.1007/s40841-017-0079-y.

${ }^{43}$ Ocean Ripeka Mercier, Christine Asmar, and Susan Page, "An Academic Occupation: Mobilisation, Sit-in, Speaking Out and Confrontation in the Experiences of Māori Academics," The Australian Journal of Indigenous Education 40 (2011): 81-91, https://doi.org/10.1375/ajie.40.81.

${ }^{44}$ Mercier, Asmar and Page, "An Academic Occupation," 81-91.

${ }^{45}$ Puwar, Space Invaders.

${ }^{46}$ Sutherland, Early Career Academics in New Zealand; Kidman and Chu, "Scholar Outsiders in the Neoliberal University," 7-19.

${ }^{47}$ Kidman and Chu, "We're Not the Hottest Ethnicity," 489-99; Naepi et al., "The Pakaru 'Pipeline,"” 142-59; Naepi et al., "A Cartography of Higher Education," 81-99; Naepi, "I Didn't Come to Play," 5269.

${ }^{48}$ Anne Edwards, "Relational Agency: Learning to Be a Resourceful Practitioner," International Journal of Educational Research 43, no. 3 (2005): 168-82, https://doi.org/https://doi.org/10.1016/j.ijer.2006.06.010; Sutherland, Early Career Academics in New Zealand.

${ }^{49} \mathrm{Ka}$ 'ili, "Tauhi Vā," 83-114.

${ }^{50}$ Amituanai-Toloa, "Tapuia (Space Made Sacred)," 200-219.

${ }^{51}$ Ka'ili, "Tauhi Vā," 83-114.

${ }^{52}$ Ka'ili, "Tauhi Vā," 83-114.

${ }^{53}$ Asmar and Page, "Pigeonholed, Peripheral or Pioneering?," 1679-91; Coates, Trudgett, and Page, "Indigenous Higher Education Sector," 1-7; McAllister et al., "Why Isn’t My Professor Māori?" 235-49. 